\title{
NOVA1 Promotes SMN2 Exon 7 Splicing via Binding the UCAC Motif and Increases SMN Protein Expression
}

Lili Du

Nantong University

Junjie Sun

Nantong University

Zhiheng Chen

Nantong University

Yixiang Shao

Nantong University

Liucheng Wu( $\nabla$ hnwulc@ntu.edu.cn )

Nantong University https://orcid.org/0000-0002-8053-1340

\section{Research Article}

Keywords: spinal muscular atrophy, motor neuron, NOVA1, YCAY motif, SMN2 splicing

Posted Date: August 12th, 2021

DOI: https://doi.org/10.21203/rs.3.rs-798194/v1

License: (c) (1) This work is licensed under a Creative Commons Attribution 4.0 International License. Read Full License 


\section{Abstract}

Spinal muscular atrophy (SMA) is a rare hereditary neuromuscular disease with high lethality rate in infants. Homologous genes SMN1 and SMN2 were reported to be SMA pathogenic factors. Studies showed that high inclusion of SMN2 exon 7 increased SMN expression which in turn ameliorated the severity of SMA. The inclusion rate of SMN2 exon 7 was higher in neural tissues than that in non-neural tissues. Expression of splicing factors that regulate inclusion of SMN2 exon 7 were significantly increased in neural tissues compared to non-neural ones. A positive correlation was checked between expression of neuro-oncological ventral antigen 1(NOVA1) and SMN in central nervous system. In addition, reduced number of neurons in the spinal cord anterior horn was determined by Nissl staining in SMA mice from postnatal day 1 to 7 continuously. Meanwhile, NOVA1 was presented in motor neurons and gradually decreased as SMA ongoing. Moreover, SMN2 exon 7 inclusion and protein level were enhanced by overexpressing NOVA1, while the enhancement was reversed when NOVA1 knockdown in vitro. Finally, the "YCAY" motif ( $Y$ is pyrimidine, $U$ or $C$ ) was located in the exon 7 of SMN2 and was critical for NOVA1 binding and promoting the inclusion of exon 7. Mutagenesis experiments revealed that CA was essential for the exon 7 inclusion while less influence was detected by changing order of $Y$ in the motif. Collectively, NOVA1 interacted with "YCAY" motif in exon 7 of SMN2 and thus enhanced the inclusion of exon 7 in SMN2 which in turn increased the level of SMN protein. Our data may provide new insights into the treatment of SMA disease.

\section{Introduction}

Spinal muscular atrophy (SMA), a rare hereditary neuromuscular disease, is mainly characterized by degeneration of alpha motor neurons in the anterior horn of the spinal cord, which affects the innervation of skeletal muscles, leading to muscle weakness, muscle atrophy, paralysis or even death [1]. The survival of motor neuron 1 (SMN1) gene, one of the SMA pathogenic genes, was located at 5q13. Deletion of exon 7 and 8 or only exon 7 results in inability of functional full length SMN protein [2]. SMN is a protein

known for its housekeeping role in the SMN-Gemin multiprotein complex [3]. It is involved in the assembly of small nuclear protein (SnRNP), regulating the splicing of precursor mRNA (pre-mRNA), and also participating in a variety of physiological processes, including stress response, axon transport, cytoskeletal dynamics, mitochondrial and bioenergy pathways, and ubiquitin pathways [4]. Please insert a sentence on the inadequacy of current study on SMN.

Two homologous genes, SMN1 and SMN2, were reported to be presented in human genome. The 6th nucleotide was $\mathrm{C}$ in exon 7 of $S M N 1$ gene, while a $\mathrm{T}$ in the same location of $S M N 2$ gene. Although $S M N 2$ can produce stable SMN protein as $S M N 1$, while only $10 \%$ of the transcripts was full length that encoded stable SMN protein, the rest was exon 7 truncated (SMN $\Delta 7$ ) transcripts that produced truncated proteins without biological functions and extremely unstable [5]. Hence, the variation of the 6th nucleotide was the key factor that influenced inclusion of exon 7 [6]. Clinical studies have shown that the severity of SMA disease is negatively correlated with the amount of functional SMN protein and SMN2 copy numbers [7, 8]. Amount of full-length $S M N$ protein generated by SMN2 is not sufficient to compensate for the defect 
of $S M N 1$, however, promoting the inclusion of $S M N 2$ exon 7 can effectively ameliorate the severity of SMA disease and improve survival of patients [9-11]. Hence, transcripts of SMN2 gene that exon 7 included or excluded account more and more importance in treatment of SMA disease.

Alternative splicing is one of the important mechanisms that regulate protein diversity and the complexity of gene abundance, and is involved in the occurrence and development of many diseases. Two types of splicing factor (SF) are involved in regulating pre-mRNA splicing. A typical type I SR protein that promotes splicing of pre-mRNA contains an RNA recognition motif (RRM) and RS region with repetitive sequences of serine and arginine $[12,13]$. While type II SFs inhibit splicing of pre-mRNA, for example the HNRNPs protein with KH domain [14]. Related studies have shown that the splicing factor NOVA, which is specifically expressed in neurons, exhibits splicing promotion or inhibition depending on which binding sites the protein located [15]. The SR and HNRNP protein families have been proved to play an important role in the regulation of $S M N 2$ splicing $[16,17]$. For example, Hua Yimin et al. blocked the binding of HNRNP A1/A2 to the intron splicing silencer located in SMN2 intron 7, and thus significantly increased the inclusion of SMN2 exon 7 and up-regulated the expression of full-length SMN protein [18]. Moreover, the nerve-specific expressed splicing factor NOVA exerted key role in the development of neural system and neurological diseases [19], while the relationship between NOVA family and SMA disease remains unclear.

Here, according to the tissue specificity of SMN2 exon 7 inclusion and splicing factor expression in Taiwanese SMA mouse model, we screened out NOVA1 that closely related to SMN2 exon 7 inclusion from a great number of splicing factors. At the same time, the dynamic expression of NOVA1 in tissues from SMA mice at different age was correlated with the progress of SMA disease. In vitro, the regulatory mechanism of NOVA1 on SMN2 exon 7 inclusion was revealed by the minigene system and RNA pull down experiment. This study will provide new ideas for correcting SMN2 gene splicing and SMA disease treatment.

\section{Materials And Methods}

\section{Animals}

Total 50 mice of SMA mice (genotype $s m n^{-/-} S M N 2^{2 t g / 0}$ ) and littermate control ones (genotype $s m n^{+/-}$ $S M N 2^{2 t g} / 0$ ) at P1, P4 and P7 were used in this study. The background strains are FVB inbred mice. The parental mice were donated from Hua-Lab of the Institute of Neuroscience in Soochow University, and were cultured in the Specific pathogen free (SPF) barrier system in Experimental Animal Center of Nantong University, where the animal experiment was carried out. All mice were free to water and food, and the light cycle was $12 \mathrm{~h}$ light and $12 \mathrm{~h}$ dark. The use of experimental animals adhered to the $3 \mathrm{R}$ principle, and the animal experiment had been approved by the Experimental Animal Ethics Management Committee of Nantong University (IACUC No. 20181008-088). The raise condition and the ethic number should be supplied. 


\section{RT-PCR}

Total RNA was extracted from tissues or cell line by TRIzol reagent following the protocol of the manufacturer (Vazyme R401-01). In brief, $1 \mu \mathrm{g}$ of each RNA sample was used per $20 \mu \mathrm{L}$ reaction for firststrand CDNA synthesis with oligo (dT) 18 and M-MLV reverse transcriptase. The RT-PCR reaction system used to detect the inclusion level of $S M N 2$ exon 7 was $12.5 \mu \mathrm{L} 2 \times$ Taq master mix (Vazyme P112), $1 \mu \mathrm{L}$ Forword primer, $1 \mu \mathrm{L}$ Reverse primer, $1 \mu \mathrm{L} \mathrm{cDNA}$ and $9.5 \mu \mathrm{L} \mathrm{ddH} 20$. The above mixture were amplified using $28 \mathrm{PCR}$ cycles, including $95^{\circ} \mathrm{C}$ for $15 \mathrm{~s}, 60^{\circ} \mathrm{C}$ for $30 \mathrm{~s}$ and $72^{\circ} \mathrm{C}$ for $45 \mathrm{~s}$, which was using to detect SMN2 exon 7 inclusion level in SMA mice. Primers was as follows: E6-F: Cy5-5'-

ATAATTCCCCCACCACCTCCC-3', E8-467R: 5'-TTGCCACATACGCCTCACATAC-3'. RT-PCR reaction procedure used for detecting the inclusion level of SMN2 exon 7 at cell level was 26 cycles $95^{\circ} \mathrm{C}$ for $15 \mathrm{~s}, 60^{\circ} \mathrm{C}$ for $30 \mathrm{~s}$ and $72^{\circ} \mathrm{C}$ for $25 \mathrm{~s}$. Primers used for RT-PCR were as follows: SMNT7F2: 5'-

TACTTAATACGACTCACTATAGGCTAGCCTCG-3', Ex8-29to52-R: Cy5-5'-TCTGATCGTTTCTTTAGTGGTGTC$3^{\prime}$.

PCR products were separated on $2 \%$ agarose gels, followed signals were quantitated by Image $\mathrm{J}$ software, and exon 7 inclusion was calculated by a formula: Exon 7 inclusion \% $=[\mathrm{FL}$ (exon 7 inclusion)/ $(\mathrm{FL}+\Delta 7($ exon 7 exclusion $))] \times 100 \% \square$

\section{qPCR}

The optional parameters for $10 \mu \mathrm{L}$ qPCR reaction system was $5 \mu \mathrm{L} 2 \times$ ChamQ Universal SYBR qPCR Master Mix (Vazyme Q711), 0.5 $\mu \mathrm{L}$ Forword primer, $0.5 \mu \mathrm{L}$ Reverse primer, $1 \mu \mathrm{L} \mathrm{cDNA}$ and $3 \mu \mathrm{L} \mathrm{ddH2O}$. PCR reaction procedure was 45 cycles $95^{\circ} \mathrm{C}$ for $10 \mathrm{~s}, 60^{\circ} \mathrm{C}$ for $20 \mathrm{~s}$, and $72^{\circ} \mathrm{C}$ for $20 \mathrm{~s}$.

The primer sequence used for qPCR were as Supplementary (Table 1)『and the mRNA levels showed by heat maps.

\section{Western blot}

Protein samples were separated by $10 \%$ SDS-PAGE and electroblotted onto PVDF membranes (Millipore FFP39), followed by $5 \%$ skim milk as blocking solution which can block non-specific bands. Then they were incubated with primary antibody overnight at $4{ }^{\circ} \mathrm{C}$ and secondary antibody for $2 \mathrm{~h}$ at room temperature. Among them, primary antibodies were respectively anti-SMN antibody (BD Biosciences, 610647), anti-NOVA1 antibody (Abcam ab183024) and anti- $\beta$-actin antibody (Santa Cruz sc-47778). Secondary rabbit anti-mouse (D110087) and goat anti-rabbit antibodies (D110058) were purchased from Sangong. Protein signals were detected with the Tanon-5200Multi Gel Imaging System (Tanon Science \& Technology).

\section{Nissl staining}

Nissl staining are carried out according to the kit (Beyotime C0117). Mouse is anesthetized on ice, then the spinal cord tissue is taken out, fixed with $4 \%$ formaldehyde at $4{ }^{\circ} \mathrm{C}$ overnight, washed in phosphate 
buffered saline (PBS) and embedded in paraffin blocks. $4 \mu \mathrm{m}$ paraffin sections were cut for Nissl Staining. In brief, the paraffin sections were dewaxed, rehydrated and washed twice with PBS for 2 minutes each time. Subsequently, put the tissue section in Nissl staining solution and stain for 3-10min at room temperature. Wash the stained sections with pure water twice, each for a few seconds. The tissue sections were dehydrated twice with $95 \%$ ethanol, each dehydration time was $2 \mathrm{~min}$. Xylene was transparent twice, each time for 5 minutes. Finally, seal the sheet with neutral gum.

\section{Immunofluorescence}

The spinal cord tissues were fixed with $4 \%$ formaldehyde at $4{ }^{\circ} \mathrm{C}$ overnight, dehydrated with $30 \%$ sugar solution and embedded in Tissue Freezing Medium (O.C.T), $6 \mu \mathrm{m}$ frozen sections by freezing microtome were rehydrated before immunofluorescence staining. In brief, the frozen sections were placed in an oven at $60^{\circ} \mathrm{C}$, dried for 30 minutes, washed twice with PBS for 2 minutes each, and were incubated with $0.3 \%$ Triton X-100 permeabilization solution at room temperature for 30 minutes. After washing with $0.01 \mathrm{M}$ PBS, add 5\% BSA blocking solution and block for 30 minutes at room temperature. Dilute the primary antibody (anti-NOVA1 Abcam ab183024; anti-ChAT antibody: Abcam ab34419) with 0.01M PBS in proportion, add it dropwise to the sliced tissue, and place it in a humid box in a refrigerator at $4^{\circ} \mathrm{C}$ overnight. Wash 3 times with $0.01 \mathrm{M}$ PBS, 5min each time. Dilute the secondary antibody (Cy3-Goat antiRabbit IgG Sangong D110062 and FITC-Donkey Anti-Chicken IgY Sangong D110201) and DAPI (Sangong E607303) with 0.01M PBS proportionally, and incubate for $2 \mathrm{~h}$ in a humid box at room temperature in dark. Wash 3 times with $0.01 \mathrm{M}$ PBS, $15 \mathrm{~min}$ each time. Mount the slide with a fluorescent mounting tablet and take pictures in the dark.

\section{Plasmid construction}

The specific construction method of SMN2 minigene was similar to those previously described by HuaLab [16]. The vector used for NOVA1 overexpression plasmid was pCGT7. The multiple cloning sites are $\mathrm{Xbal}$ and Kpnl. Nhel and Xbal are homologous enzymes. This feature can be used to construct the NOVA1 overexpression plasmid. Primer sequences used for NOVA1 overexpression plasmid were as follow: hNOVA1 Nhe1-F: 5'- ATGCTAGCATGATGGCGGCAGCTCCC-3', hNOVA1 Kpn1-R: 5'ACGGTACCTCAACCCACTTTCTGAGG-3'. PCR reaction system was $4 \mu \mathrm{L} 5 \times$ Phusin HF buffer, $0.4 \mu \mathrm{L} 10 \mathrm{mM}$ dNTPs, $1.2 \mathrm{Ml}, 1.2 \mu \mathrm{L}, 1 \sim 10 \mathrm{ng}$ cDNA, $1.2 \mu \mathrm{L}$ DMSO, $0.3 \mu \mathrm{L}$ Phusion DNA polymerase, and ddH2O which added to make up to $20 \mu \mathrm{L}$. Reaction procedure was 45 cycles, including $95^{\circ} \mathrm{C}$ for $15 \mathrm{~s}, 60^{\circ} \mathrm{C}$ for $20 \mathrm{~s}$ and $72^{\circ} \mathrm{C}$ for $20 \mathrm{~s} / \mathrm{kb}$. The PCR product was purified with PCR clean-up kit (Axygen AP-PCR-250). Through restriction enzyme digestion, ligation, transformation, amplification, plasmid extraction, and sequencing to verify the amplification results, finally NOVA1 overexpression plasmid was obtained.

\section{Cell culture and transfection}

The human glioma cell line U87MG and the human embryonic kidney (HEK293T) cells were cultured in Dulbecco's modified Eagle's medium (DMEM) (Hyclone SH30243.01) supplemented with 10\% (v/v) FBS (LONSERA S711-001S), 100U/mL penicillin and $100 \mu \mathrm{g} / \mathrm{mL}$ streptomycin (HyClone SV30010), which were 
cultured at $37^{\circ} \mathrm{C}$ in a humidified $5 \% \mathrm{CO} 2$ atmosphere. $1 \mu \mathrm{g}$ of the $S M N 2$ minigene plasmid and NOVA1 overexpression plasmid or empty vector plasmid were all transfected into cells that had been planted in a 6-well plate one day in advance. After $48 \mathrm{~h}$ of transfection, cells were collected to extract RNA or protein. In the mutation experiment, SMN2 mutation minigene was also transfected with $1 \mathrm{ug}$. Transfection reagent of petroleum equipment institute (PEI) (Sigma 408727) was used to transfect plasmid. When knocking down NOVA1, the NOVA1 siRNA sequences were as follow: NOVA1-sense: 5'-AGACAAUUGUUCAGUUGCA3', antisense: 5'-UGCAACUGAACAAUUGUCU-3'. The negative control sequences were NOVA1 siNC-sense: 5'-UUCUCCGAACGUGUCACGUTT-3', antisense: 5'-ACGUGACACGUUCGGAGAATT-3'. siRNAs were designed by online software (http://biodev.extra.cea.fr/DSIR/DSIR.html) and synthesized by Shanghai Genepharma company were transfected using Lipofectamine 2000 (Life Technologies).

\section{Point mutation}

The PCR reaction system for constructing SMN2 mutation minigene was similar to that of NOVA1 overexpression plasmid. reaction condition was $94^{\circ} \mathrm{C}$ for $10 \mathrm{~s}, \mathrm{Tm}^{\circ} \mathrm{C}$ for $20 \mathrm{~s}$ and $72^{\circ} \mathrm{C}$ for $15 \sim 30 \mathrm{~s} / \mathrm{kb}$, which had 30 cycles in total. The annealing temperature was adjusted according to the primer Tm value, or the annealing temperature was determined by gradient PCR. Mutation primers were listed in Supplementary data (Table 2). Agarose electrophoresis was used to detect the products after PCR amplification (usually $25 \mu \mathrm{L}$ reaction system). $1 \mu \mathrm{L}$ Dpnl enzyme was added to the remaining PCR product, digested in a $37^{\circ} \mathrm{C}$ water bath for 4 hours. $8 \mu \mathrm{L}$ of the product was taken for transformation after digestion, and a single colony was selected for amplification. The germs were collected and plasmids were extracted and sequenced to verify whether the mutation was successful.

\section{RNA pull down}

The biotin-labeled RNA probes, WT (5'-AGGUGCUCACAUUCCU-3') and Mut (5'- AGGUGCUCACAUUCCU-3'), were purchased from Shanghai Genepharma company, which were used for RNA pull down experiment. After washing the streptavidin agarose beads (Sigma S1638-1ML) with streptavidin washing buffer three times, biotin labeled RNA was added to the precleared beads, and the mixture was incubated at $4{ }^{\circ} \mathrm{C}$ for 1 $4 \mathrm{~h}$ on the 100 RPM rotator. Then, the beads were precipitated and cleaned by RNA-streptavidin interaction buffer. $100 \mu \mathrm{L}$ of nucleoprotein extracted with a protein concentration of $3-5 \mu \mathrm{g} / \mu \mathrm{L}$ from U87MG cells was mixed with the beads. The tubes were kept at $4{ }^{\circ} \mathrm{C}$ overnight on the 100 RPM rotator. After centrifugation, the supernatant was discarded. An appropriate volume of protein loading buffer was added then the mixture was placed in a water bath at $90^{\circ} \mathrm{C}$ for 10 minutes. After cooling on ice, samples were centrifuged at $12000 \mathrm{rpm} 4^{\circ} \mathrm{C} 10$ minutes and the supernatant was take for western blot analysis.

\section{Statistical analysis}

The software SPSS 16.0 was used for statistically analyzing. The data were expressed as mean \pm standard deviation, and statistical significance of difference between groups was analyzed by Student's $t$ test and one-way ANOVA. $P<0.05$ indicates that the difference was statistically significant. $P<0.01$ indicates that the difference was extremely significant. 


\section{Results}

\section{Inclusion of SMN2 exon7 was high in neural tissues}

Manipulation protein expression of SMN via SMN2 splicing regulation became an effective way for the treatment of SMA diseases. However, fewer reports were focused on the differences of inclusion of SMN2 exon 7 in the tissues involving in SMA disease individuals. This study offered certain evidences for treating SMA disease.

Severe type SMA mice harbored two copies of $S M N 2\left(s m n^{-/}, S M N 2^{2 t g / 0}\right)$ [20], and appeared symptoms similar to type I SMA patients at day 4 after birth.

To study the differences on the inclusion of SMN2 exon 7 in different tissues, we conducted research on 8 tissues: heart, liver, spleen, lung, kidney, brain, spinal cord, and muscle in SMA and control mice at postnatal day 4. Interestingly, we found that the SMN2 splicing, the inclusion of SMN2 exon 7, was different between tissues, and high rate of exon 7 inclusion were observed in nerve tissues in both SMA mice and control ones $\left(s m n^{+/}, S M N 2^{2 t g / 0}\right)($ Figure 1).

\section{Expression of Splicing Factors in control and SMA mice}

Exon inclusion or not was determined by splicing events under regulation of splicing factors. Classic splicing factors, such as HNRNP, SR and NOVA family members, have been confirmed to regulate a variety of splicing events. In order to clarify the relationship between the expression of splicing factors in SMA mice and the differential splicing SMN2 among tissues, we studied their expression in neural and non-neural tissues of SMA or control mice at postnatal day 4 by qPCR and showed as heat maps. Results showed that the expressions of 20 members of HNRNP, SR and NOVA family were different among tissues, while NOVA was highly expressed in nerve tissues in both SMA mice (Figure 2B) and control mice (Figure 2A).

\section{NOVA1 was Down-regulated with the Development of the Disease}

NOVA1 and NOVA2 were members of NOVA family. NOVA1 was predominantly expressed in the ventral spinal cord and the midbrain [21], NOVA2 was localized in the neocortex and hippocampus [22]. Meanwhile, the NOVA1-deficient mice produced by gene editing had abnormal motor neurons in the brainstem and spinal cord, then exhibited motor dysfunction, and died within 10 days after birth, similar to the symptoms of SMA mice [23]. To explore the relationship between the neuro-specific expression of the NOVA family members and progression of SMA disease, mRNA and protein levels of SMN and NOVA1 were detected in spinal cord of SMA mice at postnatal day 1(P1), 4(P4) and 7(P7).

In control mice, results showed that full length $S M N(S M N F L)$ mRNA and protein levels were significantly up-regulated from P1, P4 to P7 (Figure 3A, 3B, 3C). Meanwhile, the expression levels of NOVA1 were significantly increased at $\mathrm{P} 4$ and $\mathrm{P} 7$ compared to $\mathrm{P} 1$, and NOVA1 protein levels at $\mathrm{P} 7$ significantly enhanced compared with P4 (Figure 3D, 3E, 3F). 
In SMA mice, results showed that SMNFL mRNA and protein levels were significantly decreased from P1 to P4 and P7 (Figure 3G, 3H, 3I). Meanwhile, the expression levels of NOVA1 were significantly decreased at P4 and P7 compared to P1, and NOVA1 protein levels at P7 significantly decreased compared with P4 (Figure 3J, 3K, 3L).

\section{NOVA1 expressed in motor neurons and decreased with the development of SMA mice}

Results above showed that the expression of NOVA1 was correlated with that of SMA pathogenic protein SMN. Nissl staining showed that the number of the neurons in spinal anterior horn decreased continuously from P1, P4 to P7 when compared to control mice (Figure 4A).Bundles of hollow Nissl positive plaque were found in the SMA anterior horn regions compared with that of control ones. At the meantime, we found that motor neuron marker ChAT and NOVA1 were partially co-localized in spinal anterior horn at the time points (Figure 4B). Taken together, NOVA1 expression was correlated with splicing of SMA related gene SMN2, SMN protein expression and number of motor neurons in spinal cord anterior horn in SMA mice, which indicated that NOVA1 may be involved in the development of SMA disease.

\section{NOVA1 Regulated the Inclusion of SMN2 Exon 7 in vitro}

NOVA1 may participate in the development of SMA disease. However, as a RNA binding protein, whether NOVA1 can regulate the splicing of SMN2 and affect the severity of SMA disease was unknown.

Therefore, to study the mechanism of NOVA1 on SMN2 splicing, that is, the inclusion of SMN2 exon 7, we transfected NOVA1 small interfering RNA (siRNA) and plasmid into U87MG cells.

The expression of NOVA1 mRNA (Figure 5A) and protein (Figure 5B, 5C) was decreased after knocking down by siRNA. The inclusion of SMN2 exon 7 was significantly reduced as the expression NOVA1 was obviously knocked down (Figure 5D, 5E). Meanwhile, SMN protein level was also decreased (Figure 5F, 5G). In contrast, NOVA1 mRNA (Figure 5H) and protein (Figure 5I, 5J) expression was up-regulated after plasmid transfection. Expression of NOVA1 was correlated with the inclusion rate of SMN2 exon 7 (Figure $5 \mathrm{~K}, 5 \mathrm{~L}$ ), and the protein expression of SMN was increased (Figure 5M, 5N). NOVA1 expression did not change after SMN knockdown (Supplementary Figure 1). In short, NOVA1 significantly promoted the inclusion of SMN2 exon 7 and increased the expression of SMN protein.

\section{NOVA1 Bound to the UCAC Motif on Exon 7 of SMN2}

As a very important neuro-specific splicing factor, NOVA1 binds to the YCAY motif in the mRNA precursor of target gene through its $\mathrm{KH}$ domain to regulate alternative splicing. In this motif, "CA" is the key factor to splicing regulation. Interestingly, one "UCAC" motif was found in exon 7 of SMN2 (34 to 37 bp) by sequence analysis, which was consent to YCAY motif (Figure 6A). To confirm that NOVA1 targeted the UCAC sequence to regulate the inclusion of SMN2 exon 7, mutation technology was used to delete the sequence UCAC on SMN2 exon 7 and change the "UCAC" to "UAAC" in SMN2 minigene to perform SMN2 splicing research (Supplementary Figure 2). 
SMN2 wild type and mutated minigenes were transferred into HEK293T cells for 48 hours respectively. Results showed that deletion of the sequence UCAC significantly reduced the inclusion level of SMN2 exon 7. In addition, after UCAC was mutated to UAAC, the inclusion level of SMN2 exon 7 decreased more significantly (Figure 6B, 6C).

In order to confirm that NOVA1 targeted the UCAC sequence to regulate SMN2 splicing, RNA pull down experiments were performed with biotin-labeled RNA probes of WT (UCAC) and Mut (UAAC) respectively. The nucleoprotein extract group was used as a positive control, and the RNA probe (no RNA) group was used as a negative control. Results showed that in the SMN2 WT (UCAC) group, NOVA1 was detected in the pull down protein. On the contrary, NOVA1 was not detected in the SMN2 Mut (UAAC) group (Figure $6 \mathrm{D}$ ), indicating that NOVA1 protein bound to $S M N 2 m R N A$, and the binding site was the UCAC sequence (34 to $37 \mathrm{bp}$ ) in exon 7 of SMN2.

Dealing with the YCAY motif, "CA" and the pyrimidines at both ends of the sequence are particularly important. Based on the principals of avoiding pseudo-binding site and not to form new "YCAY" binding site in SMN2 exon 7, the order of $Y$ in UCAC motif was shifted as UCAU, CCAU, and CCAC. Meanwhile, mutation in the core "CA" sequence was designed as UGAC, UUAC, UAGC, UGGC, UUGC and UCGC (Figure $6 \mathrm{E})$. We found that when the UCAC sequence was mutated to UCAU, CCAU, UGAC, UUAC, UAGC, UGGC, and UUGC, the inclusion of SMN2 exon 7 was reduced (Figure 6F, 6G, 6H). Among them, the "CA" mutation had a more significant impact on the inclusion. However, CCAC and UCGC mutations significantly upregulated the inclusion of exon 7 (Figure $6 \mathrm{~F}, 6 \mathrm{G}, 6 \mathrm{H}$ ). In short, the UCAC sequence was the key sequence for NOVA1 to specifically bind to SMN2 and regulate splicing.

\section{Discussion}

Spinal muscular atrophy, which is caused by the failure in synthesizing of functional SMN protein for the SMN1 mutation, has become one of the rare diseases that seriously affect the quality of human life. Many scholars have studied the splicing of the SMN2 gene that is parallel to SMN1 and found that promoting the inclusion of SMN2 exon 7 can effectively improve the severity of SMA disease [11].

Research on the treatment of SMA disease has never stopped, including sodium butyrate [24] and induced pluripotent stem cells [25]. Although these methods have certain prospects, their efficacy is minimal or concerning with safety issues. In recent years, gene therapy and antisense oligonucleotides become popular in the treatment of SMA. Spinraza is the first antisense oligonucleotide drug developed by Hua Yimin to treat SMA in children and adults [26]. In addition, Zolgensma, the first gene therapy drug used to treat spinal muscular atrophy in children under 2 years, was also approved by the FDA for clinical treatment in May 2019 [27]. However, multiple systems were affected in SMA disease [28], these drugs have their advantages in one or more systems while their limitation and side effects cannot be ignored. At the same time, they cannot completely and effectively cure SMA, which brings greater economic and life pressure to patients. The development of more effective SMA treatment drugs is urgently demanded. 
Alternative splicing refers to the process in which a pre-mRNA generates different splicing isoforms of mRNA through different splicing methods or selection of different splicing sites. There are five basic forms of alternative splicing, namely exon skipping, intron retention, alternative 5 ' splice site, alternative $3^{\prime}$ splice site and mutually exclusive exon [29]. Among them, exon skipping is the most common one. In humans, approximately $95 \%$ of multi-exon genes are alternatively spliced [30]. One-third of all hereditary diseases may have splicing components [31], especially in the development of the nervous system, which affects the differentiation and migration of neurons, the growth and guidance of axons and the formation and function of synapses. It has an important impact on the growth and development of nervous tissue and the occurrence of neurological diseases, such as tau protein and Alzheimer's disease [32], myelin and demyelinating diseases [33], and AMPA receptors and epilepsy [34]. As a neurological disease caused by $S M N 2$ alternative splicing, treatment of SMA disease from the perspective of splicing is currently the most prospective research direction.

There are many limitations to treatment of SMA diseases by directly targeting human beings. Mouse is a common animal model with highly homologous genome sequences and similar physiological processes to humans, and plays an important role in the research and treatment of SMA disease. SMA mouse was generated by Hung Li laboratory with symptoms similar to human SMA. they carried two copies of SMN2 gene (genotype $s m n^{-/-}, S M N 2^{2 t g / 0}$ ), and developed typical symptoms of SMA four days after birth, which indicated that gene polymorphism might exert significant role in regulating the pathological change during this period [20]. At the same time, the pathological changes in different tissues and organs of SMA mice were different. Tissue specificity of SMN2 splicing was revealed by previous studies on SMA type III mice [35], which hinted importance of splicing changes of SMN2 in SMA mice.

In this study, we also detected the inclusion of SMN2 exon 7 in 8 different tissues of SMA mice at postnatal day 4. Interestingly, we found that the inclusion of SMN2 exon 7 was different among tissues and to a highflyer degree in nerve tissues in SMA and control mice. Different expression of certain splicing factors in neural and non-neural tissues was speculated to be possible for various inclusion rates. Based on this, we selected three types of classic splicing factors HNRNP, SR and NOVA family and detected their expressions. Members of three types of classic splicing factors family, such as HNRNP, SR and NOVA, were picked out and checked to determine their expression in different tissues. Enhanced expression of NOVA1 was detected in neural tissues in both control and model mice [21]. In addition, clinical studies have shown that SMA patients onset the disease at 6 months and died of respiratory diseases before the age of 2 . Researches by Meilin Qin and others showed that the development of lung cancer and other respiratory diseases was closely related to NOVA1 $[36,37]$. NOVA1 and NOVA2 were highly expressed in lung tissues besides the brain and spinal cord in SMA mice that indicated the role of NOVA in the respiratory system.

NOVA, as splicing factor specifically expressed in nerves, can regulate the inclusion of GABAA receptor $\mathrm{Y} 2$ [38], Dcc intron 16 [39] and Sept8 exon 10b [40], thereby affecting development of the motor system, function and survival of motor neurons. In addition, NOVA is also involved in other neurological diseases, such as the occurrence and development of familial autonomic dysfunction (FD) diseases [41]. In this 
experiment, we found that the expression of NOVA1 was correlated with the inclusion of SMN2 exon 7, and was significantly down-regulated as the SMA disease progressed in SMA mice. Immunofluorescence experiments also confirmed that NOVA1 was expressed along with the anterior horn motor neurons of the spinal cord in SMA mice that might rely on its promotion on the inclusion of exon 7 in SMN2. The NOVAdeficient mice created by Kirk B Jensen and others through gene editing technology have motor dysfunction and died due to motor neuron apoptosis within 10 days after birth [23, 42]. The symptoms were similar to SMA mice studied in this experiment, suggesting an association between the expression of NOVA1 and the severity of SMA. Subsequently, we first revealed that NOVA1 was highly expressed in neural tissues and enhanced translation of SMN protein via promoting the inclusion of SMN2 exon 7.

Previous study showed that NOVA1 regulates alternative splicing by combining its $\mathrm{KH}$ domain with the YCAY motif in the target gene mRNA precursor $[15,43]$. Mutation of YCAY to YAAY can eliminate the regulatory effect of NOVA1 on alternative splicing [37]. Fortunately, the UCAC sequence was found in exon 7 of SMN2. Interestingly, when we mutated the pyrimidine combination at both ends of the UCAC sequence and the core sequence "CA" in it separately, the inclusion of SMN2 exon 7 in most mutation groups were significantly reduced, and the core sequence "CA" had more significant impact on it. Therefore, the "CA" sequence in YCAY motif is critical in NOVA1 interaction. Besides, few mutations of UCAC to CCAC or UCGC significantly promoted the inclusion of exon 7, which was speculated that these mutations might form new RNA-binding sites, and further verification was needed to determine the new splicing regulation mechanism.

Decreased synthesis and loss of function of survival motor neuron (SMN) dominated the development of SMA disease. As a ubiquitously expressed protein, SMN protein is involved in small nuclear ribonucleoprotein (snRNP) biosynthesis, pre-mRNA splicing, apoptosis, axon transport, cytoskeleton dynamics, mitochondria and bioenergy pathways and other activities [44-46]. Current study showed that with the aggravation of SMA disease, SMN protein was significantly down-regulated, which is consistent with the results of Ewout J.N. Groen et al. [47], and all the evidences confirmed temporal and spatial expression of SMN affected the severity of SMA disease. However, SMN protein was translated with the template of full length $S M N 2$ mRNA with $S M N 2$ exon 7, and its expression level was significantly downregulated when exon 7 inclusion reduced, which may not be able to synthesize snRNP normally.

Therefore, a positive correlation between SMN2 exon 7 inclusion and SMN protein expression was established. In this study, both NOVA1 and SMN proteins were simultaneously down-regulated in SMA mice. Similarly, NOVA1 up-regulated both SMN2 FL and SMN protein in vitro. Related studies have shown that SMN protein can interact with splicing factors, such as SMN and HNRNPR in the axons bodies, axon terminals and cytoplasm of mouse motor neurons [48]. So, it was speculated that there may be a proteinprotein interaction between NOVA1 and SMN protein, in other words, NOVA1 may also directly bind to SMN protein to regulate protein expression and affect the severity of SMA disease, and the regulation mechanism need further study $[49,50]$.

In short, with the continuous development of SMA disease, the expression of NOVA1, which had the same inter-tissue differences with SMN2 splicing, was significantly down-regulated, and it can target binding to 
the 34 to 37 UCAC sequence in SMN2 exon 7 to regulate SMN2 splicing, which is of great significance for the treatment of SMA disease.

\section{Conclusion}

The inclusion rate of SMN2 exon 7 was higher in neural tissues, and the splicing factor of NOVA1 was higher in neural tissues too from many splicing factors. NOVA1 was presented in motor neurons and decreased as SMA ongoing. SMN2 exon 7 inclusion and protein level were enhanced by overexpressing NOVA1, while reversed when NOVA1 knockdown. NOVA1 could bind the "YCAY" motif in exon 7 thus enhanced mRNA levels of SMN2 FL and SMN protein. The data may provide new target gene of NOVA1 for treatment of SMA disease.

\section{Abbreviations}

SMA spinal muscular atrophy;

SMN survival of motor neuron;

FL Full-length;

NOVA1 neuro-oncological ventral antigen 1;

Pre-mRNA Precursor messenger RNA;

AS Alternative splicing;

SF Splicing factor;

RRM RNA recognition motif;

HNRNP Heterogenous nuclear ribnucleoprotein;

snRNP Small nuclear ribonucleoprotein;

SR Serine-arginine protein;

SPF Specific pathogen free;

\section{Declarations}

Acknowledgements We thank Professor Yimin Hua for providing SMA mice and guidance in constructing SMN2 minigene.

Author contribution Liucheng Wu and Junjie Sun designed the experiments and supervised the project. Lili Du, Junjie Sun, Liucheng Wu and Zhiheng Chen performed the experiments. Liucheng Wu and Junjie 
Sun analyzed the results. Yixiang Shao gave suggestions for the experiments and analysis. Lili Du and Liucheng Wu wrote the manuscript. Liucheng Wu and Junjie Sun revised the manuscript.

Funding This work was funded by grants from Science and Technology Project of Nantong City, grant number JC2018090, Graduate Research and Innovation Projects of Jiangsu Province, grant number KYCX18-2415, National Natural Science Foundation of China, grant Numbers 32000841.

Availability of Data Data and material used to support the study are included inthis article.

Ethics Approval Not applicable.

Consent to Participate Not applicable.

Consent for Publication Authors consent for the publication of the manuscript.

Conflict of Interest The authors declare no competing interests of this manuscript.

\section{References}

1. Arnold ES, Fischbeck KH: Spinal muscular atrophy. Handb Clin Neuro/ 2018, 148:591-601.

2. Brzustowicz LM, Lehner T, Castilla LH, Penchaszadeh GK, Wilhelmsen KC, Daniels R, Davies KE, Leppert M, Ziter F, Wood D et al: Genetic mapping of chronic childhood-onset spinal muscular atrophy to chromosome 5q11.2-13.3. Nature 1990, 344(6266):540-541.

3. Borg RM, Bordonne R, Vassallo N, Cauchi RJ: Genetic Interactions between the Members of the SMNGemins Complex in Drosophila. PLoS One 2015, 10(6):e0130974.

4. Chaytow $H$, Huang YT, Gillingwater TH, Faller KME: The role of survival motor neuron protein (SMN) in protein homeostasis. Cell Mol Life Sci 2018, 75(21):3877-3894.

5. Anderton RS, Meloni BP, Mastaglia FL, Boulos S: Spinal muscular atrophy and the antiapoptotic role of survival of motor neuron (SMN) protein. Molecular neurobiology 2013, 47(2):821-832.

6. Lefebvre S, Burglen L, Reboullet S, Clermont O, Burlet P, Viollet L, Benichou B, Cruaud C, Millasseau P, Zeviani $\mathrm{M}$ et al: Identification and characterization of a spinal muscular atrophy-determining gene. Cell 1995, 80(1):155-165.

7. Lefebvre S, Burlet P, Liu Q, Bertrandy S, Clermont O, Munnich A, Dreyfuss G, Melki J: Correlation between severity and SMN protein level in spinal muscular atrophy. Nat Genet 1997, 16(3):265-269.

8. Wirth B: An update of the mutation spectrum of the survival motor neuron gene (SMN1) in autosomal recessive spinal muscular atrophy (SMA). Hum Mutat 2000, 15(3):228-237. 
9. Hua Y, Sahashi K, Rigo F, Hung G, Horev G, Bennett CF, Krainer AR: Peripheral SMN restoration is essential for long-term rescue of a severe spinal muscular atrophy mouse model. Nature 2011, 478(7367):123-126.

10. Wu X, Wang SH, Sun J, Krainer AR, Hua Y, Prior TW: A-44G transition in SMN2 intron 6 protects patients with spinal muscular atrophy. Hum Mol Genet 2017, 26(14):2768-2780.

11. Son HW, Yokota T: Recent Advances and Clinical Applications of Exon Inclusion for Spinal Muscular Atrophy. Methods Mol Biol 2018, 1828:57-68.

12. Long JC, Caceres JF: The SR protein family of splicing factors: master regulators of gene expression. Biochem J 2009, 417(1):15-27.

13. Anko ML: Regulation of gene expression programmes by serine-arginine rich splicing factors. Semin Cell Dev Biol 2014, 32:11-21.

14. Martinez-Contreras R, Cloutier P, Shkreta L, Fisette JF, Revil T, Chabot B: hnRNP proteins and splicing control. Adv Exp Med Biol 2007, 623:123-147.

15. Ule J, Stefani G, Mele A, Ruggiu M, Wang X, Taneri B, Gaasterland T, Blencowe BJ, Darnell RB: An RNA map predicting Nova-dependent splicing regulation. Nature 2006, 444(7119):580-586.

16. Hua Y, Vickers TA, Okunola HL, Bennett CF, Krainer AR: Antisense masking of an hnRNP A1/A2 intronic splicing silencer corrects SMN2 splicing in transgenic mice. Am J Hum Genet 2008, 82(4):834848.

17. Wee CD, Havens MA, Jodelka FM, Hastings ML: Targeting SR proteins improves SMN expression in spinal muscular atrophy cells. PLoS One 2014, 9(12):e115205.

18. Hua Y, Sahashi K, Hung G, Rigo F, Passini MA, Bennett CF, Krainer AR: Antisense correction of SMN2 splicing in the CNS rescues necrosis in a type III SMA mouse model. Genes Dev 2010, 24(15):1634-1644.

19. Buckanovich RJ, Posner JB, Darnell RB: Nova, the paraneoplastic Ri antigen, is homologous to an RNA-binding protein and is specifically expressed in the developing motor system. Neuron 1993, 11(4):657-672.

20. Hsieh-Li HM, Chang JG, Jong YJ, Wu MH, Wang NM, Tsai CH, Li H: A mouse model for spinal muscular atrophy. Nature genetics 2000, 24(1):66-70.

21. Graus F, Rowe G, Fueyo J, Darnell RB, Dalmau J: The neuronal nuclear antigen recognized by the human anti-Ri autoantibody is expressed in central but not peripheral nervous system neurons. Neurosci Lett 1993, 150(2):212-214. 
22. Yang YY, Yin GL, Darnell RB: The neuronal RNA-binding protein Nova-2 is implicated as the autoantigen targeted in POMA patients with dementia. Proc Natl Acad Sci U S A 1998, 95(22):1325413259.

23. Jensen KB, Dredge BK, Stefani G, Zhong R, Buckanovich RJ, Okano HJ, Yang YY, Darnell RB: Nova-1 regulates neuron-specific alternative splicing and is essential for neuronal viability. Neuron 2000, 25(2):359-371.

24. Chang JG, Hsieh-Li HM, Jong YJ, Wang NM, Tsai CH, Li H: Treatment of spinal muscular atrophy by sodium butyrate. Proc Natl Acad Sci U S A 2001, 98(17):9808-9813.

25. Corti S, Nizzardo M, Simone C, Falcone M, Nardini M, Ronchi D, Donadoni C, Salani S, Riboldi G, Magri $\mathrm{F}$ et al: Genetic correction of human induced pluripotent stem cells from patients with spinal muscular atrophy. Sci Trans/ Med 2012, 4(165):165ra162.

26. Hoy SM: Nusinersen: First Global Approval. Drugs 2017, 77(4):473-479.

27. Hoy SM: Onasemnogene Abeparvovec: First Global Approval. Drugs 2019, 79(11):1255-1262.

28. Farrar MA, Park SB, Vucic S, Carey KA, Turner BJ, Gillingwater TH, Swoboda KJ, Kiernan MC: Emerging therapies and challenges in spinal muscular atrophy. Ann Neurol 2017, 81(3):355-368.

29. Ward AJ, Cooper TA: The pathobiology of splicing. J Pathol 2010, 220(2):152-163.

30. Pan Q, Shai O, Lee LJ, Frey BJ, Blencowe BJ: Deep surveying of alternative splicing complexity in the human transcriptome by high-throughput sequencing. Nat Genet 2008, 40(12):1413-1415.

31. Lim KH, Ferraris L, Filloux ME, Raphael BJ, Fairbrother WG: Using positional distribution to identify splicing elements and predict pre-mRNA processing defects in human genes. Proc Natl Acad Sci US A 2011, 108(27):11093-11098.

32. Love JE, Hayden EJ, Rohn TT: Alternative Splicing in Alzheimer's Disease. J Parkinsons Dis Alzheimers Dis 2015, 2(2).

33. Aoyagi $Y$, Kobayashi H, Tanaka K, Ozawa T, Nitta H, Tsuji S: A de novo splice donor site mutation causes in-frame deletion of 14 amino acids in the proteolipid protein in Pelizaeus-Merzbacher disease. Ann Neurol 1999, 46(1):112-115.

34. Rogawski MA, Donevan SD: AMPA receptors in epilepsy and as targets for antiepileptic drugs. Adv Neurol 1999, 79:947-963.

35. Chen YC, Chang JG, Jong YJ, Liu TY, Yuo CY: High expression level of Tra2-beta1 is responsible for increased SMN2 exon 7 inclusion in the testis of SMA mice. PLoS One 2015, 10(3):e0120721. 
36. Qin M, Wei G, Sun X: Circ-UBR5: An exonic circular RNA and novel small nuclear RNA involved in RNA splicing. Biochem Biophys Res Commun 2018, 503(2):1027-1034.

37. Ludlow AT, Wong MS, Robin JD, Batten K, Yuan L, Lai TP, Dahlson N, Zhang L, Mender I, Tedone E et al: NOVA1 regulates hTERT splicing and cell growth in non-small cell lung cancer. Nat Commun 2018, 9(1):3112.

38. Dredge BK, Darnell RB: Nova regulates $\mathrm{GABA}(\mathrm{A})$ receptor gamma2 alternative splicing via a distal downstream UCAU-rich intronic splicing enhancer. Mol Cell Biol 2003, 23(13):4687-4700.

39. Leggere JC, Saito Y, Darnell RB, Tessier-Lavigne M, Junge HJ, Chen Z: NOVA regulates Dcc alternative splicing during neuronal migration and axon guidance in the spinal cord. Elife 2016, 5.

40. Yuan Y, Xie S, Darnell JC, Darnell AJ, Saito Y, Phatnani H, Murphy EA, Zhang C, Maniatis T, Darnell RB: Cell type-specific CLIP reveals that NOVA regulates cytoskeleton interactions in motoneurons. Genome Biol 2018, 19(1):117.

41. Herve M, Ibrahim EC: MicroRNA screening identifies a link between NOVA1 expression and a low level of IKAP in familial dysautonomia. Dis Model Mech 2016, 9(8):899-909.

42. Ruggiu M, Herbst R, Kim N, Jevsek M, Fak JJ, Mann MA, Fischbach G, Burden SJ, Darnell RB: Rescuing Z+ agrin splicing in Nova null mice restores synapse formation and unmasks a physiologic defect in motor neuron firing. Proc Natl Acad Sci U S A 2009, 106(9):3513-3518.

43. Ule J, Jensen KB, Ruggiu M, Mele A, Ule A, Darnell RB: CLIP identifies Nova-regulated RNA networks in the brain. Science 2003, 302(5648):1212-1215.

44. Schrank B, Gotz R, Gunnersen JM, Ure JM, Toyka KV, Smith AG, Sendtner M: Inactivation of the survival motor neuron gene, a candidate gene for human spinal muscular atrophy, leads to massive cell death in early mouse embryos. Proc Natl Acad Sci U S A 1997, 94(18):9920-9925.

45. Paushkin S, Gubitz AK, Massenet S, Dreyfuss G: The SMN complex, an assemblyosome of ribonucleoproteins. Curr Opin Cell Biol 2002, 14(3):305-312.

46. Fallini C, Bassell GJ, Rossoll W: Spinal muscular atrophy: the role of SMN in axonal mRNA regulation. Brain Res 2012, 1462:81-92.

47. Groen EJN, Perenthaler E, Courtney NL, Jordan CY, Shorrock HK, van der Hoorn D, Huang YT, Murray LM, Viero G, Gillingwater TH: Temporal and tissue-specific variability of SMN protein levels in mouse models of spinal muscular atrophy. Hum Mol Genet 2018, 27(16):2851-2862.

48. Dombert B, Sivadasan R, Simon CM, Jablonka S, Sendtner M: Presynaptic localization of Smn and hnRNP R in axon terminals of embryonic and postnatal mouse motoneurons. PLoS One 2014, 9(10):e110846. 
49. Singh RN, Howell MD, Ottesen EW, Singh NN: Diverse role of survival motor neuron protein. Biochimica et biophysica acta Gene regulatory mechanisms 2017, 1860(3):299-315.

50. Tadesse H, Deschenes-Furry J, Boisvenue S, Cote $\mathrm{J}$ : $\mathrm{KH}$-type splicing regulatory protein interacts with survival motor neuron protein and is misregulated in spinal muscular atrophy. Hum Mol Genet 2008, 17(4):506-524.

\section{Figures}



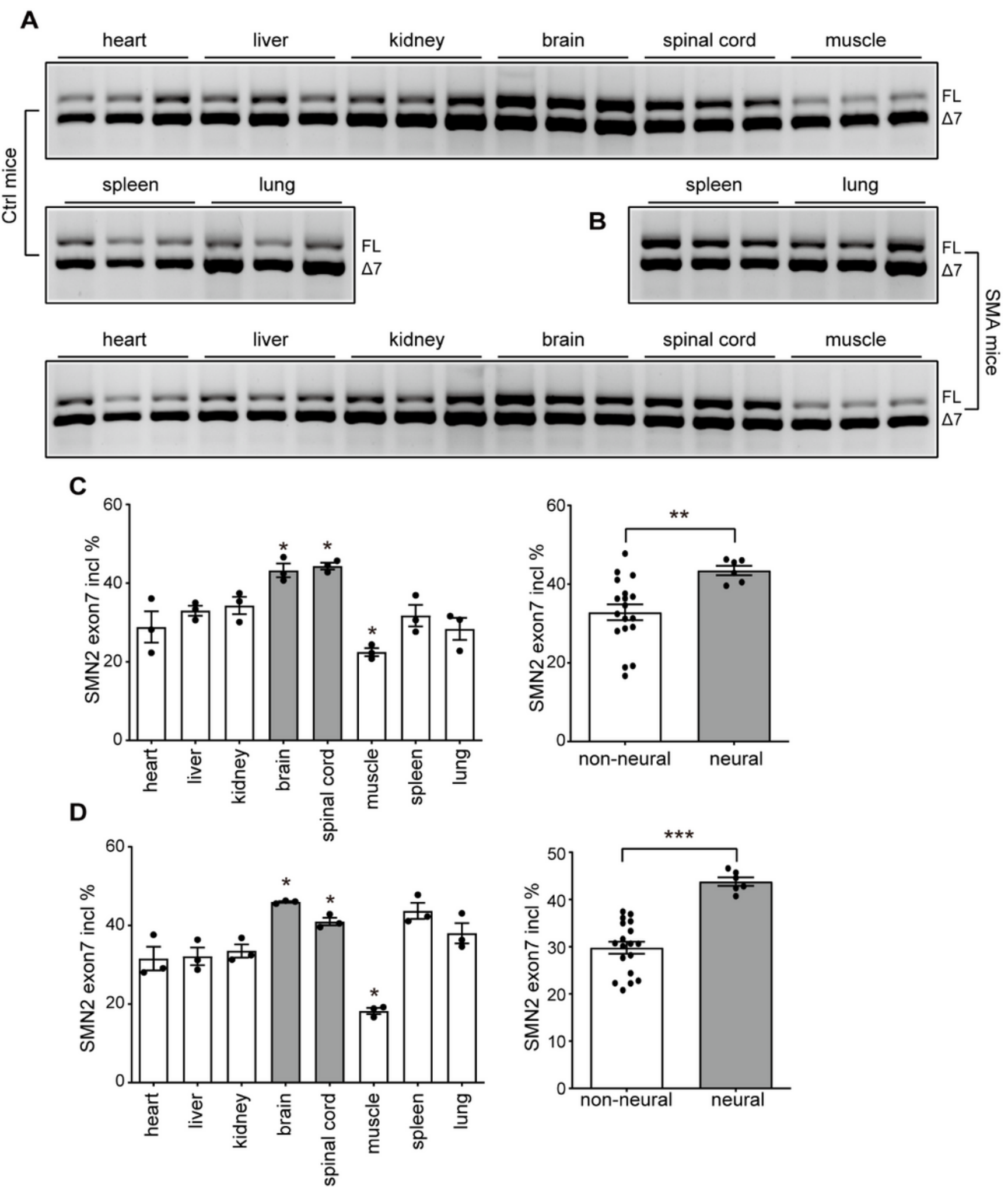

\section{Figure 1}

Expression pattern of full-length SMN2 in neural and non-neural tissues. (A) Inclusion ratio of SMN2 exon 7 in neural and non-neural tissues in control and SMA mice. (B) Relative gray density in different tissues in control mice (left panel) and average gray density in neural and non-neural tissues (right panel in B). (C) Relative gray density in different tissues in SMA mice (left panel) and average gray density in neural and non-neural tissues (right panel in $C$ ). $n=3$. ${ }^{*} P<0.05$, ${ }^{* *} P<0.01$, ${ }^{* * *} P<0.001$. 


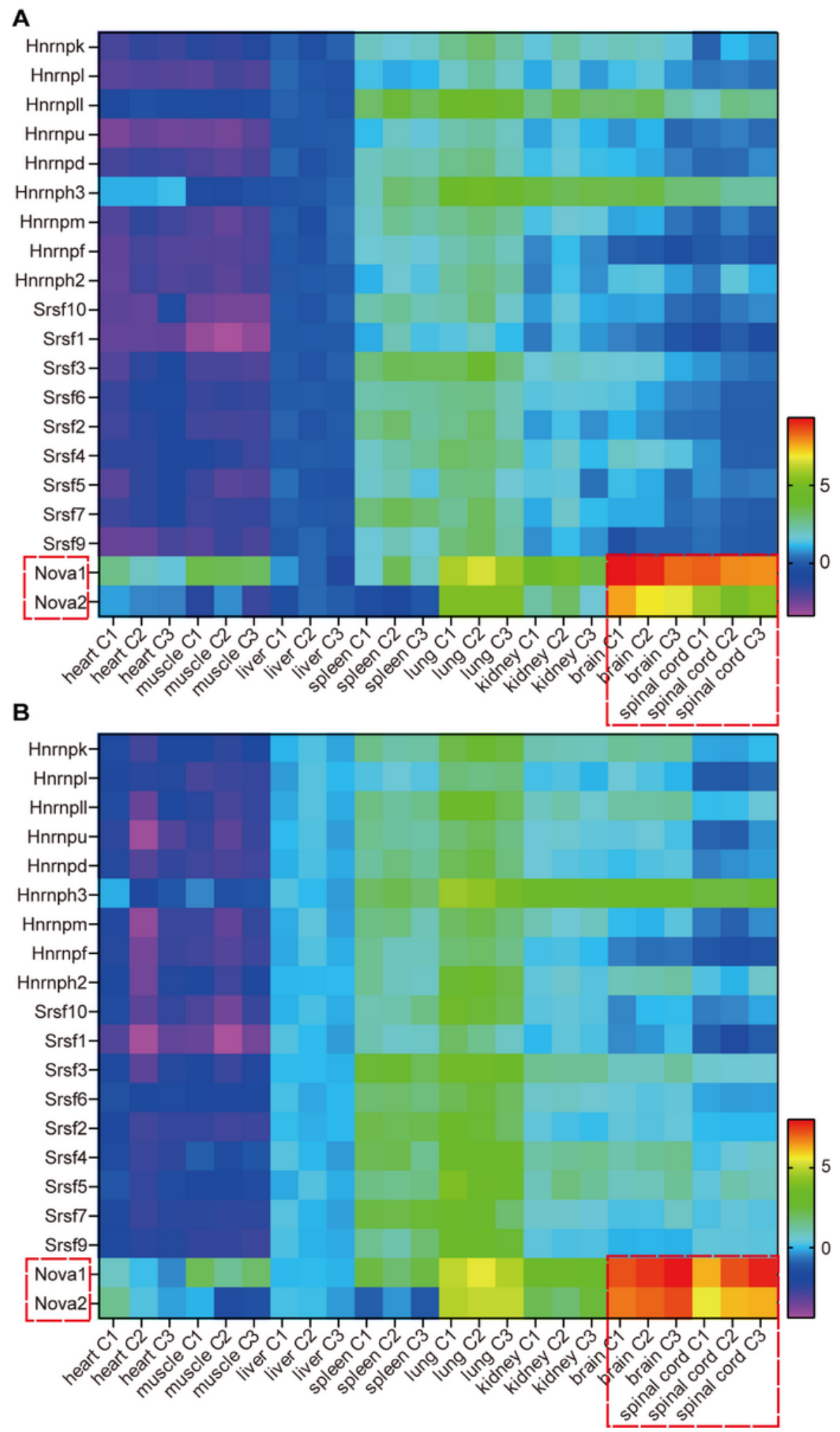

Figure 2

Expression of splicing factors in control and SMA mice. Heat map of splicing factors mRNA level in control (A) and SMA mice (B). The original data to form heat maps derived from qPCR with primers in supplementary table 1 . 

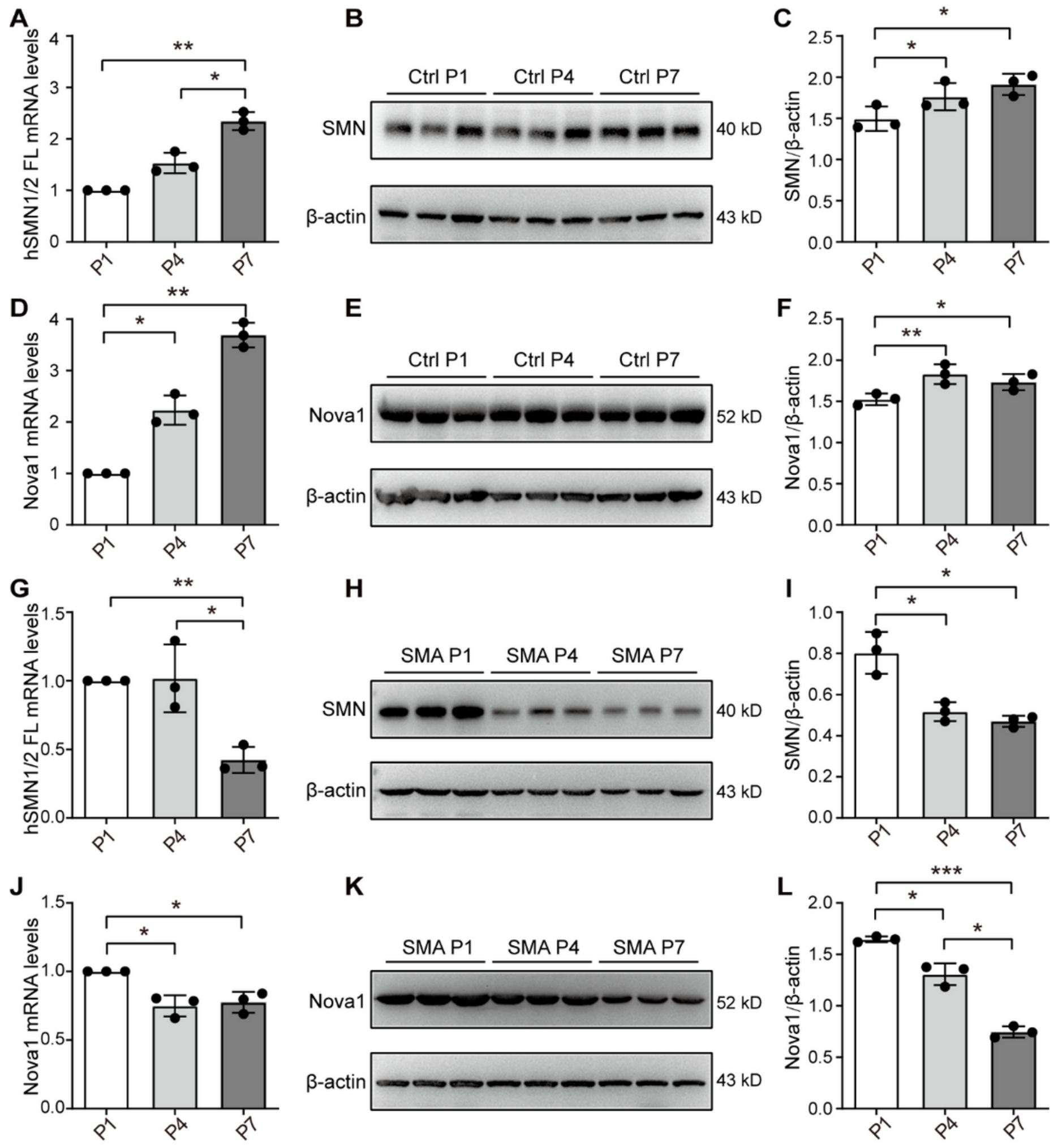

Figure 3

SMN demonstrated similar expression pattern with NOVA1 in control and SMA mice. (A, D, G, J) results of mRNA expression of control mice (A. SMN, D. NOVA1) and SMA mice (G. SMN, J. NOVA1). (B,E,H,K) results of protein expression in control mice (B. SMN, E. NOVA1) and SMA mice (H. SMN, K. NOVA1). (C, F, $\mathrm{I}, \mathrm{L})$ gray density analysis for $\mathrm{B}, \mathrm{E}, \mathrm{H}, \mathrm{K} . \mathrm{P} 1, \mathrm{P} 4$, and $\mathrm{P} 7$ indicated sample from mice at age of postnatal day 1,4 and 7. $n=3 .{ }^{*} P<0.05,{ }^{*} P<0.01, * * * P<0.001$. 
A
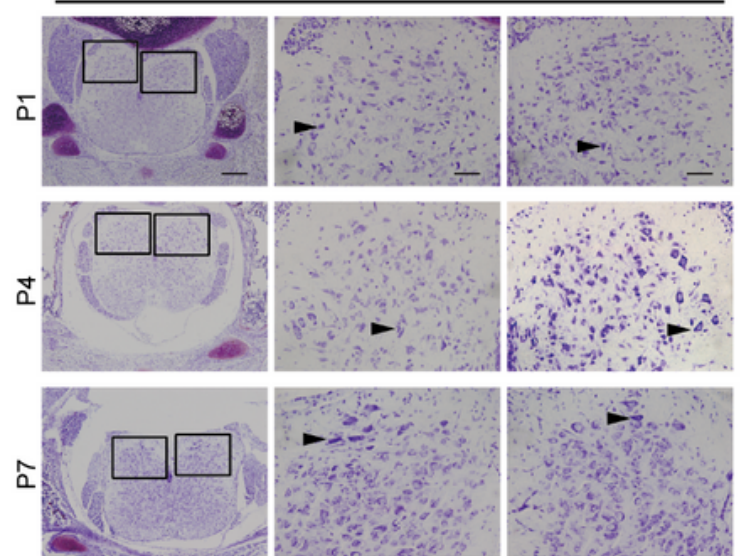

B

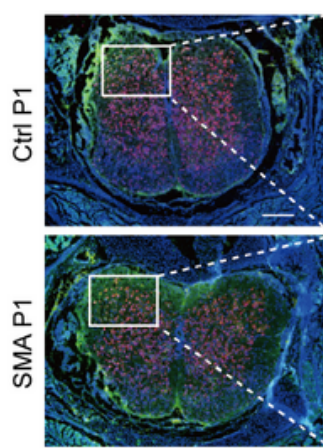

ChAT
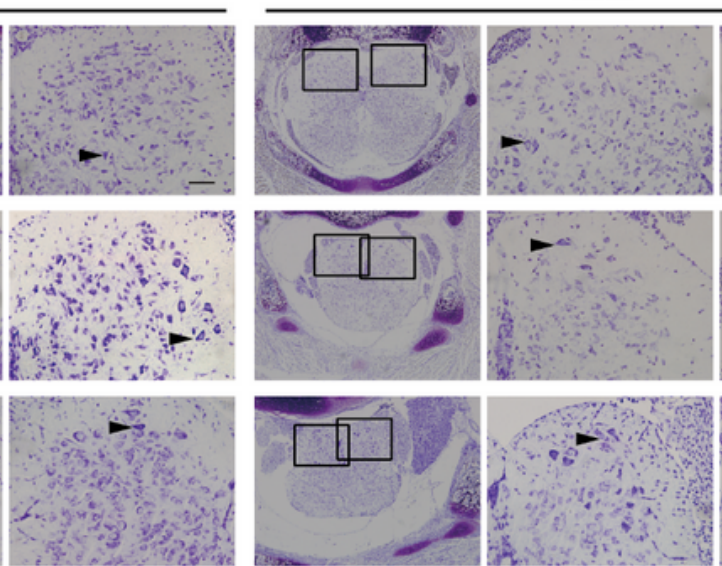

$-$

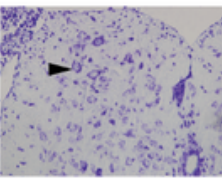

Nova1
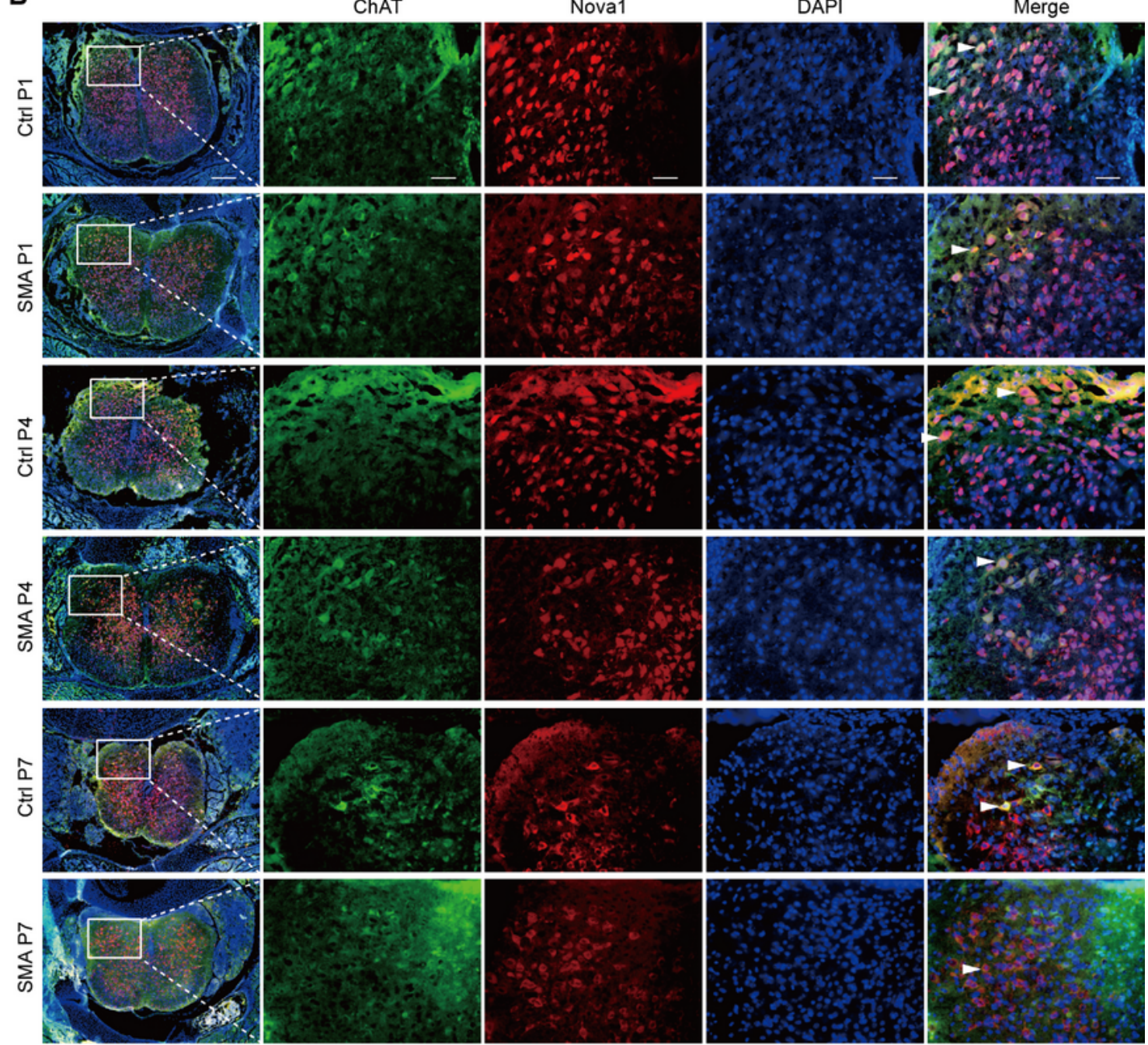

Figure 4

NOVA1 expressed in motor neurons and decreased with the development of SMA mice. (A) Nissl staining of spinal cord sections of control and SMA mice. The boxes indicated the location of anterior horn of spinal cord. Regions in box 1 and 2 was enlarged in the right panels. Arrows pointed out the neurons in site. $n=3$. (B) Immunofluorescence detection for ChAT (motor neuron, Green), NOVA1 (Red) and DAPI (Nuclear, Blue) expression in the spinal cord in control and SMA mice. The white box showed the region 
of anterior horn of spinal cord. Enlarged views of region in the boxes were demonstrated in the right panels. White arrows indicated location of motor neurons. P1, P4, and P7 indicated sample from mice at age of postnatal day 1, 4 and 7. $n=3$. Scale bar=200um \& 50um.
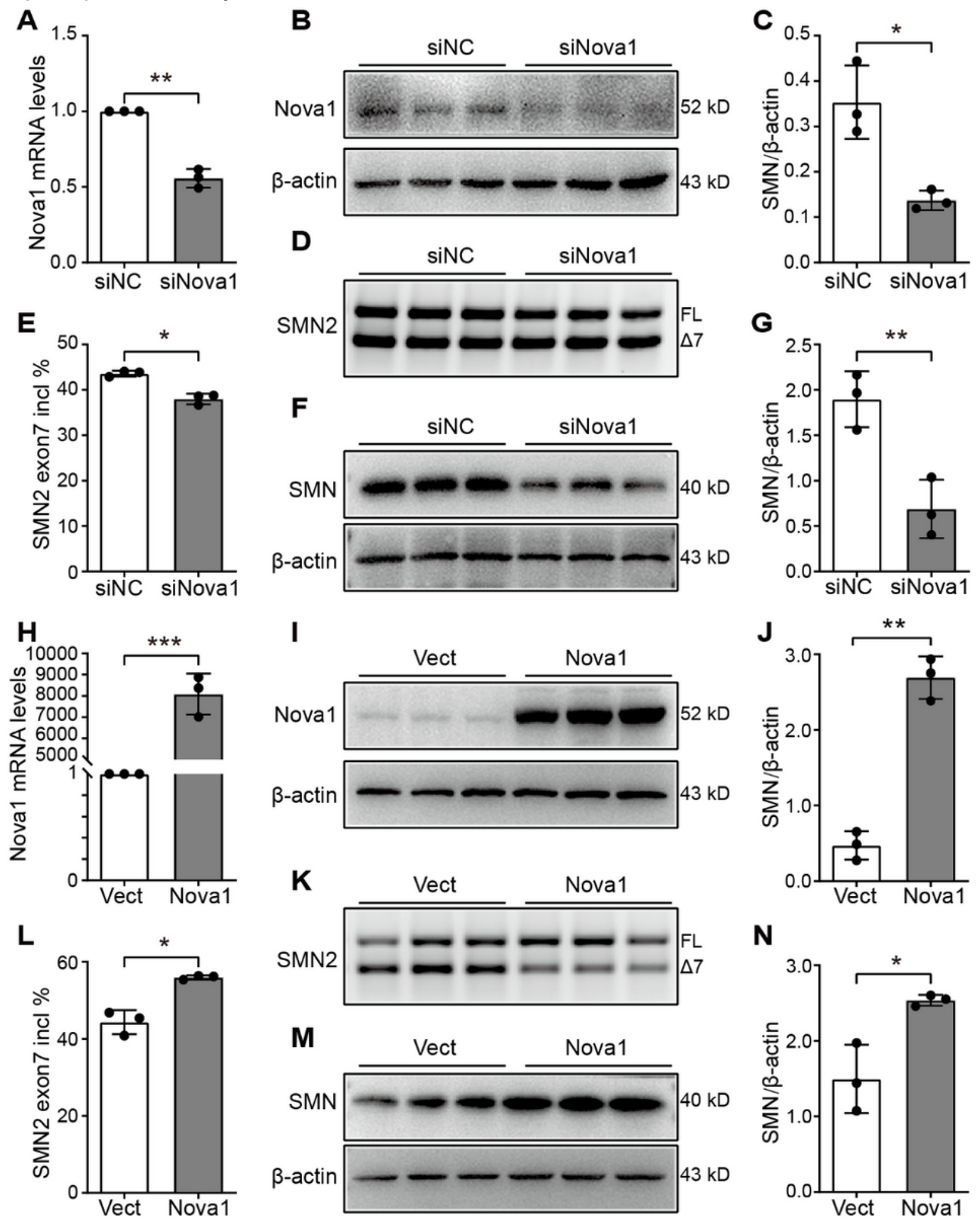

Figure 5

NOVA1 regulated SMN2 exon 7 inclusion in U87MG cells. Knockdown efficiency of NOVA1 was checked by qRT-PCR (A) and western blot (B) in U87MG cells. (C) Gray density analysis for (B). (D) Inclusion rate 
of exon 7 of SMN2 after knocking down NOVA1 and (E) statistic result of (D). (F) Protein level of SMN after NOVA1 inhibition and gray density analysis (G). Overexpression efficiency of NOVA1 was checked by qRT-PCR $(\mathrm{H})$ and western blot $(\mathrm{I})$ in U87MG cells. (J) Gray density analysis for (I). (K) Inclusion rate of exon 7 of SMN2 after overexpression of NOVA1 and (L) statistic result of (K). (M) Protein level of SMN after NOVA1 overexpression and gray density analysis $(N) . n=3 .{ }^{*} P<0.05, * \star * P<0.01 .{ }^{*} * * P<0.001$.

A

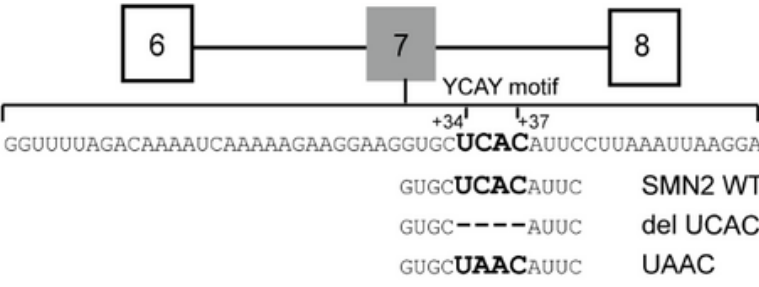

B

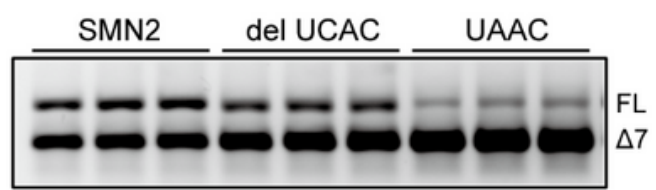

C

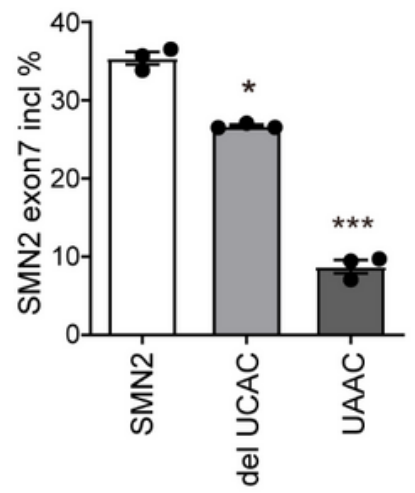

$\mathbf{F}$

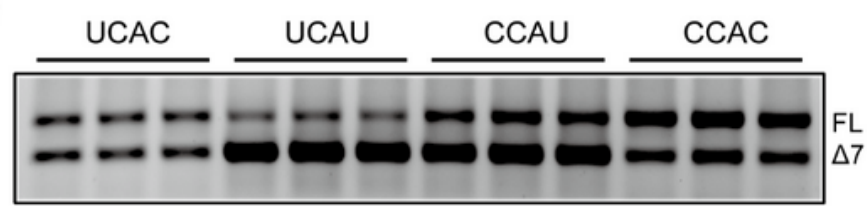

G

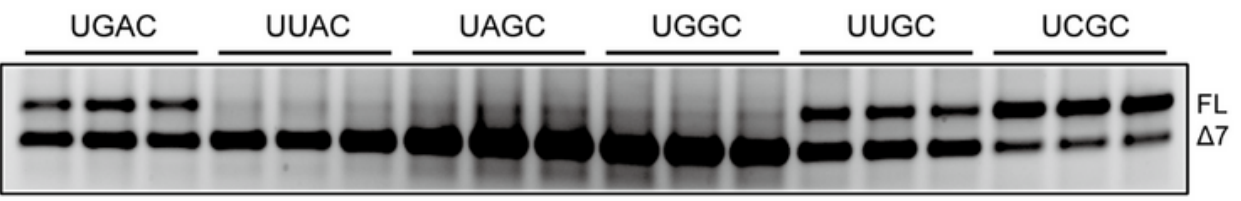

H

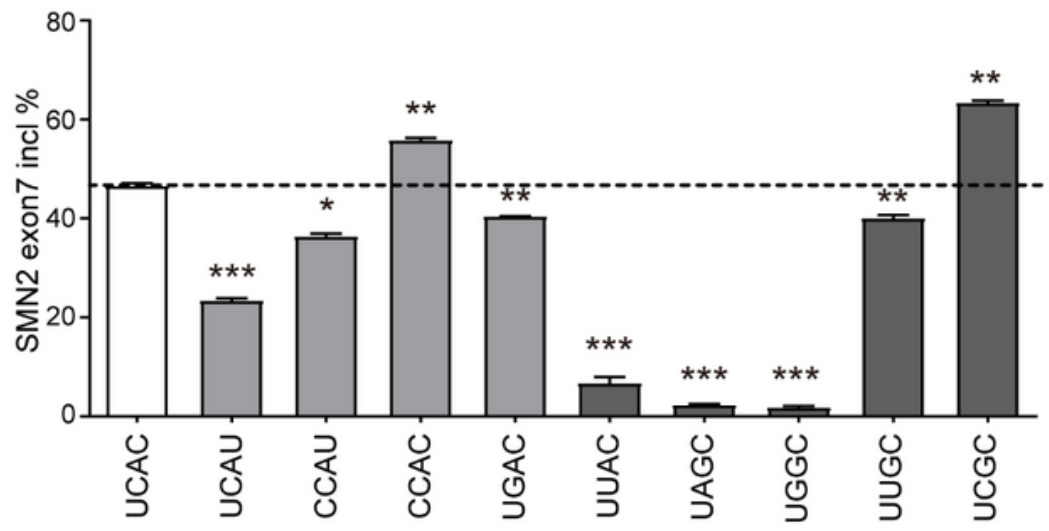

Figure 6 
The UCAC motif was the binding site of NOVA1 and played an important role in SMN2 splicing. (A) Schematic diagram of SMN2 minigene with NOVA1 binding site on exon7. (B) Inclusion of SMN2 exon7 under condition of UCAC deletion and UAAC mutation. (C) Statistic analysis for (B). (D) Western blot detection of NOVA1 protein after RNA pull down. (E) Schematic diagram of UCAC mutation cassette. (F) Detection of SMN2 splicing after mutation of pyrimidine in UCAC sequence. (G) Determination of SMN2 splicing after mutation of CA in UCAC sequence. $(H)$ Statistical graph based on $(F)$ and $(G)$. Compared to the UCAC, $* P<0.05, * * P<0.01, * \star * P<0.001$.

\section{Supplementary Files}

This is a list of supplementary files associated with this preprint. Click to download.

- Supplementary.docx 